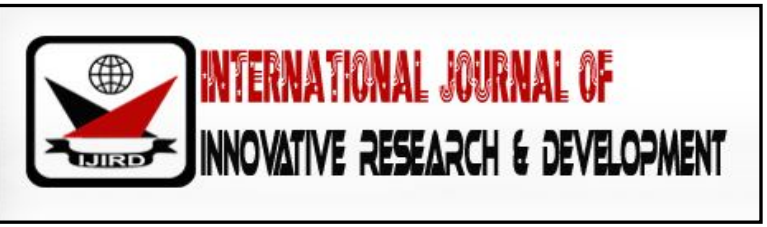

ISSN 2278 - 0211 (Online)

\title{
Assessment of Learners' Preparedness for Digital Learning as Supplement of Self-Learning Materials in Private and Public Universities in Kenya
}

\author{
Dr. George Makori \\ Lecturer, Egerton University, Kenya \\ Dr. Fedha Flora \\ Lecturer, Egerton University, Kenya
}

\begin{abstract}
:
Due to an over whelming population and increasing demand, it is not possible for country like Kenya to provide higher education to all who really need it through formal mode. Open and Distance Learning (ODL) is one of the best alternatives to satisfy the growing demand for education of a variety of learners, it is important to understand their availability and utilization based on gender at the university level. For this reason, this study conducted a comparative assessment of how computers, telecommunication and audio-visual systems are used in different universities in Kenya (both public and private) particularly within teacher education. Descriptive survey using the ex post facto study design was utilized. The study used three hundred (300) fourth year Bachelor of Education students who were selected using the stratified random sampling method from universities in Kenya. Questionnaires were discussed with research supervisors and other experts to enhance their validity. Reliability was determined using the Cronbach alpha method and a reliability coefficient of 0.70 was considered acceptable. Data from the questionnaires was analyzed using the Statistical Package for Social Sciences (SPSS) version 17.0. The findings are: Lecturers and students were using various ICTS frequently for educational purposes but needed additional training and encouragement on utilizing of some, need for appropriate technical support to utilize various ICTs for learning and teaching. Unreliable electricity/ power supply contributed negatively to its effective utilization. Lastly Universities had no ICT-use policies to guide teacher education students and lecturers. Among the recommendations: The universities should design and conduct ICT-use courses among teacher education students and lecturers in universities in Kenya, strengthen the technical support, invest in alternative power sources and implement ICT-use policies that can be integrated into teacher education programmes.
\end{abstract}

Keywords: Digital learning, self learning materials, learners, utilization of ICTS

\section{Introduction}

The onset, the $21^{\text {st }}$ century is extremely dynamic in almost all spheres of human endeavour and particularly in Information and Communication Technology (ICT). Information is being transmitted rapidly within and between nations in ways previously unimagined. Educational practice must incorporate this new technology (Pittman, 2007). New technological innovations in education (such as E-Learning, Electronic/ Digital libraries and diverse software programmes) are appearing at an ever accelerating pace, paralleling the rapid increase of innovations in the general society (Eynon, 2005). At the same time, computers have become one of the indispensable elements of our modern lives. Providing new opportunities for delivering information, and easing communication and resource sharing, ICTs are also challenging educational institutions to integrate ICTs into their curricula and utilize them in some ways (Simsek, 2008). As a result, many researchers have directed their attention to these new pedagogical tools and started to investigate their utility in relation to what face-to-face courses offer from the perspectives of students, teachers and educational institutions (for example Butcher et al 2003; Pittman, 2007; Wims \& Lawler, 2007; Sanchez \& Salwas, 2008; UNU, 2008; Unwin, 2008; Czerniwicz \& Brown, 2009, among others).

While reflecting on ICTs, it is important to direct attention to their use in higher education in the $21^{\text {st }}$ century. This is because higher education is particularly crucial for economic growth since it provides higher level skilled workers and is an important source of inventive outputs. By extension, the role of universities as centres of research and diffusion of findings of the same will become increasingly important in this century (Oyelaran-Oyeyinka \& Adeya, 2004). Secondly, higher education 
produces skilled engineers and scientists whose skills and knowledge drive the industrialization process. Again, as competitiveness becomes less price-based and more innovation driven, the dual role of universities (as research and training centres) will become the decisive factor in transforming economies.

Open Distance learning has been used to describes any of a number of instructional situations. Although it is thought of as a new term, distance learning has been around for well over 100 years. One of the earlier forms of distance learning was done through correspondence courses started in Europe and remained the primary means of distance learning until the middle of this century when instructional radio and television became more popular (Valentine, 2002). The change in technology has seen the change in the definition of distance learning. Videotaped lectures have been a standard in university and professional courses for the last two decades (Moore \& Lockee, 1998). Audiotapes and lessons sent through the mail have been used in correspondence courses to teach subjects such as foreign language for quite some time.

The Internet is perhaps the most remarkable technological breakthrough of the 1990s. Undoubtedly, it will continue to play an important role in transforming higher education itself just as the universities have contributed in remarkable ways in generating new technologies in ICT, life sciences and biotechnology (Rosenberg, 2001). Information and Communication Technologies (ICTs) are generally accepted as instrumental to enabling educators to modify the teaching methods they use in order to increase the students interest. The extended use of ICTs has created a knowledge-based society where information plays an important role for the research work, training efforts and students' satisfaction in the universites (Valasidou \& Bousiou, 2005).

Hoffman (2001) suggested that successful implementation of ICTs need to address five interlocking frameworks for change: the infrastructure, attitude, staff development, support (technical and administrative) and also sustainability and transferability. There are different kinds of ICTs implemented at teaching and learning such as tele- and video-conferencing and e-learning tools. These products can be used in education for different purposes. Some of them help students with their learning by improving the communication between them and the instructors (Valasidou, Sidiropoulos, Hatzis \& Bousiou, 2005). In this regard (UNESCO, 2002a \& UNESCO, 2002b) have provided some practical answers to the challenges posed by ICTs to the teaching profession.

In line with global efforts to achieve the Millennium Development Goals (MDGs) as outlined by the United Nations Development Programme (UNDP) and other United Nations (UN) agencies, teacher training initiatives across the world should be reviewed. Motivated and well trained teachers will be instrumental if the MDGs for Kenya are to be achieved by 2015 (UNDP, $2003 \&$ UN, 2004). Given the very great importance of teacher training, it is surprising that more emphasis is not placed on its enhancement by national governments, donors and civil society organizations alike.

The number of students interested in taking courses from a distance for convenience and financial reasons have been on the increase over the years. The problem that the School confronts with is how the learners could enhance this learning activity with digital learning materials. Many institutions of higher learning have adopted online education in -order to provide flexibility to the learning environment. The major handicaps are that the learner have no access with the teaching learning resources without which its not feasible to introduce teaching through digital. The question here is therefore assessing the state of preparedness of university students by gender to receive and offer courses online?

Teacher training is all too often neglected in the face of more immediately visible educational goals and objectives; it is much easier to build a gleaming new school in an urban community than it is to train successfully a cadre of teachers willing to work in poor rural areas, far from centres of social and commercial life (Unwin, 2005). In the EFA global monitoring report for 2002, UNESCO (2002d) emphasized that some three million new teachers are required in Africa if the MDGs are to be achieved. Over and above this, there is a pressing need for teachers with a minimal level of training to have opportunities to upgrade their skills and qualifications (Unwin, 2005).

Since 2003 the Ministry of Education, Science and Technology (MOES\&T) in Kenya has embarked on major reforms in the education sector. The National Conference on Education and Training held on November 2003 mandated the MOES\&T to develop a new policy framework for the education sector (GoK, 2005). As a result, the Sessional paper which was developed constitutes the Government of Kenya policy on Education and Training (GoK, 2005). The policy discusses teacher development and utilization of ICTs. In the university sub-sector, the Ministry for Higher Education, Science and Technology appointed a Taskforce for the development of a National Strategy for University Education in February 2006 among whose strategic goals was the integration of ICTs into university education and to increase innovation and research output of Kenyan universities (GoK, 2008). In addition to these efforts, the Government of Kenya has promulgated a National ICT policy (GoK, 2006). Through this ICT policy, the government aspires to encourage the use of IT in schools, colleges and universities and other educational institutions especially for ODL.

\subsection{Statement of the Problem}

The number of students interested in taking courses from a distance for convenience and financial reasons have been on the increase over the years. ICTs are essential to stimulate national development and international competitiveness. Most countries especially in the developed world have not only integrated the use of ICTs in their primary and secondary school curricula but made ICTs a core component of open distance teacher education and teacher development programs. Many institutions of higher learning have adopted online education in -order to provide flexibility to the learning environment. While there is fair documentation on how ICTs are and can be utilised to achieve maximum benefits for education in 
developed countries, there is little such information on a developing country like Kenya, that is, the state of preparedness of university students by gender to receive and offer courses online; whether are there public and private universities differences with regard to their application of such ICTs, the challenges faced using ICTs in teacher education.

\subsection{Objectives of the Study}

The proposed study was guided by the following objectives:

- Compare public and private universities with regard to the availability and utilization of ICTs in teacher education;

- Establish the challenges facing the utilization of ICTs in teacher education in universities in Kenya;

\subsection{Research Design}

The study was a descriptive survey that adopted the ex post facto design to gather data. Surveys gather data at a particular point in time with the intention of describing the nature of existing conditions, or identifying standards against which existing conditions can be compared (Moser \& Kalton, 1971; Cohen \& Manion, 1997). The ex post facto design was considered appropriate for this study in order to analyse and describe how ICTs are used in teacher education in various universities in Kenya. This is because the manifestation of how they are utilised cannot be manipulated (Mugenda \& Mugenda, 1999). The survey was useful in establishing what functions the ICTs are used for in universities in Kenya, whether public and private universities differ with regard to their application of such ICTs, the challenges faced while using ICTs in teacher education, and possible solutions to such challenges. In this way, insight into the types of ICTs that exist were gained as well as understanding of the similarities and differences in their utilization.

\subsection{Target Population}

The target population for this study included students and lecturers in faculties, schools or colleges of education in public and private universities in Kenya that offer teacher education. The public universities offering teacher education are: University of Nairobi, Kenyatta, Egerton, Moi, Maseno and Masinde Muliro universities. The private ones are: University of Eastern Africa (Baraton), Kabarak University and Catholic University of Eastern Africa, CUEA (ACU, 2005). Together with those that are admitted in the private universities and those who enrol under self sponsored programmes, the working figure for this study was 3000 fourth year Bachelor of Education students.

\subsection{Sampling Procedures and Sample Size}

The sample for the study was drawn from universities in Kenya. The universities were selected using stratified random sampling procedures. They were stratified into public and private universities. From each stratum, two universities were selected purposefully as shown in Table Two, below. Egerton University was considered on the basis of its top ranking for ICT use in Kenya; ranked 21 overall in Africa and 4,110 worldwide (www.webometrics.info), while Kenyatta University is the oldest university in Kenya offering teacher education. Both CUEA and Baraton were the first private universities to offer Bachelor of Education programmes.

\section{Findings and Discussions}

The results are presented and discussed in line with the objectives of the study, in the following sequence:

- Compare public and private universities with regard to the extent of utilization of ICTs in teacher education;

- The influence of user characteristics on utilization of ICTs among teacher education students in universities in Kenya;

- Establish the challenges facing the utilization of ICTs in teacher education in universities in Kenya;

\subsection{Types of ICTS among Teacher Education Students in Public and Private Universities in Kenya}

The first objective of the study sought to identify the variety and functions performed by ICTs among teacher education students and lecturers in universities in Kenya.

\subsection{Students' Responses on types of ICTs among Teacher Education Students in Public and Private Universities in Kenya}

The students were asked to indicate the types of ICTs they used frequently (on and off campus); the frequency of use; their perceived degree of competence in the use of ICTs; their preferences of various ICTs for academic and non-academic uses; and the reasons for using them. A comparison of private and public universities on each of these aspects is also presented. 


\begin{tabular}{|c|c|c|}
\hline Type of ICT & Private (\%) & Public (\%) \\
\hline Mobile Telephone & 92 & 60 \\
\hline The Internet & 91 & 88 \\
\hline Computer Labs & 85 & 80 \\
\hline Television & 82 & 39 \\
\hline Laptop Computer & 43 & 36 \\
\hline Radio & 37 & 39 \\
\hline
\end{tabular}

Table 1: Comparison of Students' Use of ICT on Campus in Private and Public Universities

Source: Field Data

The results show that private universities had a markedly higher use of identified ICTs on campus compared with public universities. On the one hand, in regard to the ICT types identified, both university types reported high use of the internet and computer labs but comparatively lower use of laptop computers. The results also show that private university students had a higher use of the mobile telephone on campus compared with the public university students. From the results in Table 1, both university types indicated a high use of internet and computer labs. This implies that both private and public universities had invested substantially on ICT infrastructure for use by their students and therefore communication with their students in ODL is enhanced.

The use of the mobile telephone and television on campus was higher in private universities at $92 \%$ and $82 \%$, compared to $60 \%$ and $39 \%$ in public universities, respectively. These points to the advantage of lecturers understanding use of mobile as one important resource to reach distance teacher students. With regard to laptop computers, private and public university students reported low use of the ICT type at $43 \%$ and $36 \%$, on campus respectively. This is mainly because fewer students could afford to buy their own laptop computers. The findings may imply that financial initiatives by various providers were needed so that more laptops may be made available to students if the ODL objectives can be met.

The study also investigated the frequency of use of various ICTs among private and public university students off campus. The results were as shown on Table 2:

\begin{tabular}{|c|c|c|}
\hline Type of ICT & Private (\%) & Public (\%) ) \\
\hline Radio & 70 & 63 \\
\hline Television & 65 & 60 \\
\hline Mobile Telephone & 55 & 38 \\
\hline The Internet & 45 & 21 \\
\hline Laptop Computer & 35 & 11 \\
\hline Computer Labs & 17 & \\
\hline \multicolumn{2}{|c|}{ Table 2: Comparison of Students' Use of ICT off Campus in Private and Public Universities } \\
\end{tabular}

The results in Table 2 show that private university students had a higher off campus usage of all the ICTs except the mobile telephone. The results also show that both categories of respondents reported lower results for Internet, laptop computer and computer labs usage. The results further show that public university students reported higher mobile telephone usage off campus (61\%) than their private counterparts (55\%). The explanation for this may be that while some of them do not use mobile telephones on campus; more opportunities are available to use the telephones off campus. Such mobile telephones may be those belonging to parents and other family members or friends, among others. The results on higher internet use by private universities ( $45 \%$ against 38\%) point to the possibilities implied earlier that some of them may access the internet on the parents' telephones or probably others have internet connections at their homes. It may also be concluded from the results that students used radio and television for entertainment purposes while off campus, more than the other ICT types.

These results on off campus use of ICTs suggest that although the students relied on institutional ICTs for internet and computer related needs, they still had access to some ICTs while off campus, albeit to a lower extent. This may also imply that universities need to explore the potential that exists in adjusting their training programmes so as to provide the possibilities of their students to accessing online learning resources off campus. Students can also receive other formats of learning materials such as take away CDs or DVDs with content which they can interact with while off campus, among other numerous possibilities such as utilizing SMS as a means of communicating important information ( like opening dates, upcoming events or other urgent alerts).

A comparison of how frequently students used ICTs in both private and public universities was undertaken to establish their usage patterns as shown on Table 3: 


\begin{tabular}{|c|c|c|}
\hline Frequency of ICT Use & Private & Public \\
\hline Every Day & 30 & 10 \\
\hline $2-3$ times per Week & 33 & 39 \\
\hline Once a Week & 26 & 32 \\
\hline Once a Month & 8 & 11 \\
\hline Rarely/ Never & 3 & 8 \\
\hline
\end{tabular}

Table 3: Comparison of Students' Frequency of ICT Use for Study Purposes Based on University Type

Source: Field Data

The results in Table 3 show that although a majority of students in both university types used ICTs frequently, private university students had a higher usage at $89 \%$ compared with their counterparts from public universities at $81 \%$. This frequent use of ICTs for study purposes by students is also reported by Kirkwood (2007); Baro, Onyenania and Osaheni (2010). Kirkwood (2007), for example asserted that 73\% of the undergraduate students surveyed in the UK reported that ICT use was important in their everyday study life. On their part, Baro et. al. (2010) noted that $87 \%$ of the undergraduate students in three Nigerian universities used various ICTs daily to source information relevant to their courses.

A comparison of students' competence with various ICTs in both private and public universities was undertaken to establish their usage patterns as shown on Table 4:

\begin{tabular}{|c|c|c|}
\hline ICT Application & Private & Public \\
\hline E-mail (receiving and sending) & 95 & 92 \\
\hline Word processing & 94 & 90 \\
\hline PowerPoint (for presenting information) & 74 & 61 \\
\hline Video Files & 51 & 47 \\
\hline Audio files & 49 & 47 \\
\hline Discussion Forums (such as Instant Messenger) & 45 & 43 \\
\hline Digital Libraries ( or online libraries and databases) & 33 & 31 \\
\hline
\end{tabular}

Table 4: Comparison of Students' Competence with ICT Applications

Source: Field Data

The results from Table 4 show that private university students had a higher usage of various ICTs compared to their public university counterparts. The Table also shows that students in both university categories reported higher competencies with regard to e-mail, word processing and power point. However, fewer students indicated that they had relevant skills on other ICT applications (search engines, audio and video files, discussion forums, and the use of digital libraries). This is perhaps due to the fact that such application required a higher level of technical training that was not available to all students an area that requires attention.

A comparison of students' ICT use preferences for various academic purposes in both private and public universities was undertaken to establish their usage patterns. The results are as shown on Table 5.

\begin{tabular}{|c|c|c|}
\hline $\begin{array}{c}\text { N= 224 } \\
\text { Academic Activities }\end{array}$ & Private & Public \\
\hline $\begin{array}{c}\text { Sending e-mail to Lecturer about course issues } \\
\text { (take away tests, assignments or reports) }\end{array}$ & 64 & 57 \\
\hline Doing assignments and other course related tasks or homework & 62 & 55 \\
\hline Class discussions or tutorial presentations & 58 & 51 \\
\hline General reference to supplement lecture notes & 60 & 53 \\
\hline
\end{tabular}

Table 5: Comparison Of Students' Preference for ICTs In Private and Public Universities Source: Field Data

The results in Table 5 clearly show that there were differences in ICT preferences for academic purposes between private and public university students. The major implication of the findings in Table 5 is that despite the institution type in which they were enrolled, students preferred to use ICTs to contact their lecturers, to do their assignments, to conduct class 
discussions and for general reference this is encouraging noting that numbers in institutions of higher learning is on increase therefore this positive response shows students willingness and preference for ODL.

In summary, the students' responses on first objective of the study on functions of ICTs for teacher education revealed that they used various ICTs (the Internet, computer resource rooms/laboratories, laptop computers, mobile telephones, television and radio both on and off-campus. These ICTs were used frequently for academic functions such as communication with their lecturers on course matters, submitting assignments, class discussions, tutorial presentations and general reference in their studies, despite the existing challenges related to the use of the various media. The students also utilized the ICTs for non-academic functions that included sending of e-mails to their friends and others, social networking, and manipulation of media files (both audio and visual), among others. The findings of the study further showed that despite some knowledge/ skill gaps that were reported, the students had sufficient relevant skills to utilize the ICTs in their studies.

\subsection{Influence of Gender on Utilization of ICTs among Teacher Education Students in Universities in Kenya}

The study investigated the influence of students' gender on: use of ICT on and off campus by, students' competence and frequency of use of ICTs. Table 6 presents findings on students' on and off campus use of ICTs by gender:

\begin{tabular}{|c|c|c|c|c|}
\hline \multirow{2}{*}{ Type of ICT } & \multicolumn{2}{|c|}{ Male (N=114) } & \multicolumn{2}{c|}{ Female (N=110) } \\
\cline { 2 - 5 } & f & $\mathbf{\%}$ & f & \% \\
\hline Internet & 100 & 88 & 101 & 74 \\
\hline Mobile Telephone & 91 & 91 & 81 & 60 \\
\hline Desktop Computer & 72 & 64 & 66 & 55 \\
\hline Television & 76 & 67 & 60 & 51 \\
\hline Radio & 71 & 63 & 56 & 37 \\
\hline Laptop Computer & 50 & 44 & 40 & \\
\hline
\end{tabular}

Table 6: Students' ICTs Use on Campus by Gender

Source: Field Data

The results in Table 6 show that although females reported higher internet use than males (92\% against 88\%), males reported higher use of all other ICT types (mobile telephone, desktop computer, television, radio and laptop computer). The Table also shows that fewer students used laptops on campus (44\% and 37, respectively), compared to other types of ICT probably because of the high cost of obtaining laptops. These findings have various implications on the use of ICTs among teacher education students in universities in Kenya. For example, universities were making significant investments in ICT facilities for student use. At the same time, parents, sponsors, guardians and other stakeholders have facilitated students to acquire various ICT devices especially the mobile telephone that enable them to access the internet. These findings indicate that use of ICTs on campus among male and female students was comparable.

On the use of ICTs off-campus based on gender, Table 7 shows the students' responses.

\begin{tabular}{|c|c|c|c|c|}
\hline \multirow{2}{*}{ Type of ICT } & \multicolumn{2}{|c|}{ Male (N=113) } & \multicolumn{2}{c|}{ Female (N=110) } \\
\cline { 2 - 5 } & f & \% & f & 38 \\
\hline Internet & 41 & 36 & 42 & 53 \\
\hline Mobile Telephony & 72 & 64 & 58 & 21 \\
\hline Desktop Computer & 28 & 25 & 23 & 63 \\
\hline Television & 58 & 52 & 69 & 68 \\
\hline Radio & 74 & 65 & 75 & 29 \\
\hline Laptop Computer & 28 & 25 & 32 & \\
\hline
\end{tabular}

Table 7: Students' ICTs Use off - Campus Based on Gender

Source: Field Data

Results in Table 7 show that there was a higher use of ICTs like radio, mobile telephone and television off campus by both male and female students, compared to other ICTs. Comparatively, it was noted that female students reported higher off campus use of radio and television while males had higher off-campus use of mobile telephone. These findings may imply that females preferred to follow programmes of choice flexibly and conveniently through radio or using the FM radio features on their mobile telephones. They also preferred to watch television than their male counterparts. The findings on mobile telephony and internet use implied that male students preferred to communicate via mobile telephones (voice calls and short messages) while it is possible that females used the internet for communication (e-mail and other social network services), among other uses. It can also be observed further that while various types of ICTs were availed in central places on campus (typically the computer labs, the common rooms, dining halls or cafeterias), students who stayed off campus had access to the television and radio as part of the household facilities. It can also be observed from these results that fewer male and female students used desktop computers off campus, compared with other types of ICTs implying a reliance on institutional ICT 
facilities. These studies point to the conclusion that though students use ICTs off-campus, they relied significantly on institutional ICTs, a fact observed by this study as well.

2.4. Students' ICT Competence

The second dimension of this objective was concerned with students' ICT competence based on gender. The results were as shown on Table 8.

\begin{tabular}{|c|c|c|c|c|}
\hline & \multicolumn{2}{|c|}{ Male (n=114) } & \multicolumn{2}{c|}{ Female (n=110) } \\
\hline ICT Application & \multicolumn{2}{|c|}{ f } & \multicolumn{2}{c|}{ f } \\
\hline E-mail & 105 & 92 & 100 & 90 \\
\hline Word Processing & 103 & 91 & 103 & 94 \\
\hline Search Engines (Google, Yahoo!, Bing, etc) & 77 & 68 & 48 & 44 \\
\hline Instant Messenger & 72 & 64 & 75 & 68 \\
\hline PowerPoint & 68 & 60 & 82 & 74 \\
\hline Video Files & 63 & 56 & 48 & 43 \\
\hline Audio files & 61 & 54 & 45 & 41 \\
\hline Digital Libraries & 38 & 34 & 31 & 28 \\
\hline
\end{tabular}

Table 8: Student Competence with Software Applications and Technologies Based on Gender Source: Field Data

The results in Table 31 show students ICT competence for carrying out such functions as communication, word processing, entertainment and social interaction. Comparatively, more males than females reported higher competence on the use of e-mail and search engines. However, more females than males reported higher competencies on applications such as Word Processing; Power Point presentations and Instant Messenger.

Both male and female students indicated that they were proficient in the use of e-mail (at $92 \%$ and $90 \%$, respectively). This implies that many students perceived themselves as having reasonable mastery of the application and that educational practitioners in higher education can utilize this competency (Tapscott, 2009). There were high numbers of both male and female students who reported that they used the basic word processing and handling applications (Word and PowerPoint). These applications are important for educational purposes especially day to day preparation of documents and class presentations or assignments. The use of Audio files, Video files and Web-based sources of content is utilized by more males than females. This may imply that males tend to have an affinity to tasks which tend towards manipulation (So, Choi, Lim \& Xiong, 2012). Female students indicated that they utilized chats (68\%) more than males implying that they had stronger social tendencies that made them to share their feelings and thoughts more (Carrier et al, 2009).

\subsection{Students' Frequency of ICT Use Based on Gender}

The study was also interested on a third dimension of this objective to establish the frequency of ICT use for study purposes among male and female students. Table 9 shows the cross tabulation of gender and frequency of ICT use for study purposes.

\begin{tabular}{|c|c|c|c|c|c|}
\hline & Every day & $\begin{array}{c}\text { 2-3 times per } \\
\text { week }\end{array}$ & Weekly & Monthly & Rarely/ Never \\
\hline Male & $15 \%$ & $44 \%$ & $28 \%$ & $9 \%$ & $4 \%$ \\
\hline Female & $26 \%$ & $28 \%$ & $30 \%$ & $9 \%$ & $7 \%$ \\
\hline
\end{tabular}

Table 9: Frequency of ICT Use for Study Purposes by Gender

The Table shows that those who used ICTs for study purposes from everyday to weekly accounted for $87 \%$ for males and $84 \%$ for females. This shows that a high percentage of students of both gender had reasonable access to ICT facilities and that they used them frequently. This is encouraging if ODL has to be effective at all. This finding on frequency of ICT use for study purposes among male and female students is in agreement with other studies. For example, Junco et al (2010) pointed out that the original gender gap in computer and internet use appears to have narrowed down to the point of nonexistence. Mahmood (2009) also agrees that today gender has no significant effect on the frequency of student ICT use.

\subsection{Challenges Facing Utilization of ICTs among Teacher Education Students' in Universities in Kenya}

This section presents the responses on the challenges facing the utilization of ICTs among teacher education students' in private and public universities in Kenya. Table 10 shows the students' responses. 


\begin{tabular}{|c|c|c|}
\hline Challenges & Private (\%) ) & Public (\%) \\
\hline Lack of a personal computer & 83 & 97 \\
\hline Unreliable internet connectivity & 61 & 70 \\
\hline Lack of computer mastery & 60 & 47 \\
\hline Lack of technical support & 52 & 62 \\
\hline Insufficient computers on campus & 43 & 57 \\
\hline Lack of training for others & 44 & 58 \\
\hline Lack of interest among staff & 40 & 40 \\
\hline Lack of personal interest in ICTs & 39 & 47 \\
\hline Unreliable electricity & 29 & 57 \\
\hline
\end{tabular}

Table 10: Students' Challenges on Use of ICTs in Private and Public Universities Source: Field data

Table 10 shows that the major challenges facing both private and public university students were lack of personal computers (that they neither own a laptop nor a desktop computer) and unreliable internet connectivity. The Table shows that more public university reported lack of personal computers off campus as a leading constraint to their use of ICTs for educational purposes than their private counterparts. The results also show that internet connectivity in both private and public universities was sometimes unreliable perhaps due to instances of low speeds or factors such as poor server maintenance, virus or hacker attacks, cabling problems, among other causes. This made it difficult for the students to use the internet or other online resources for educational purposes as much as they would have wanted to. The findings also reveal that $60 \%$ of the students in private universities (compared with $47 \%$ of their public counterparts) reported lack of computer mastery as a constraint to their use of ICTs for education. This may mean that some students did not feel confident to undertake basic computer operations such as using search engines to look for information on the internet or to undertake word processing on their own.

The results in Table 10 also show that students in both university types reported lack of technical support as a constraint implying that students lacked appropriate assistance while they worked with various ICTs, especially in resource rooms. This assistance is usually provided by technical staff that help students to exploit online resources, obtain print-outs of documents, write or copy CDs and DVDs, save files, download information or access certain websites. In some cases, the students noted the inadequate support staff.

The results further show that the students in public universities also reported two other notable constraints: lack of interest towards ICTs use among staff (58\%) and lack of training on ICT among their peers (57\%). It can be noted that if teaching staff had a poor attitude towards using ICTs for teaching, presentation or reference in class; students who looked up to them as role models may be negatively impacted as well. At the same time, if their colleagues did not demonstrate any interest in using ICTs, this may discourage others from using them. Some of the other challenges indicated by the students related to institutional factors like inadequate number of computers on campus and unreliable electricity which may have been due to frequent electricity 'blackouts' or power outages.

From the results, private and public university students faced similar challenges which could be classified into two ways: the external or first-order challenges and the internal or second-order challenges Policy interventions in addressing these challenges may have to be directed along these two major pathways.

\subsection{Differences in the Utilization of ICTs among Teacher Education Students in Public and Private Universities in Kenya}

$\mathrm{H}_{0}{ }^{1}$ : There is no statistically significant difference among teacher education students in use of ICTs by university type.

In order to determine whether there were any differences among teacher education students in private and public universities on use of ICTs, the means of the students' responses were generated as shown on Table 11:

\begin{tabular}{|c|c|c|c|c|c|}
\hline & Types of Universities & $\mathbf{N}$ & Mean & Std. Deviation & Std. Error Mean \\
\hline \multirow{2}{*}{$\begin{array}{c}\text { mean academic } \\
\text { use }\end{array}$} & Private & 106 & 2.6838 & 1.09682 & .10653 \\
\cline { 2 - 6 } & Public & 117 & 2.4585 & .92931 & .08591 \\
\hline
\end{tabular}

Table 11: Means of Private and Public University Students on ICT Use

The results in Table 11 show that private university students indicated a slightly higher mean than their public counterparts in use of ICTs. This finding is consistent with the observation that these universities had better ICT investments than the public universities and their ratio of various ICTs to students was lower. In contrast, the higher numbers of students in public universities had reduced the ratio of students to various ICT facilities.

A t-test was conducted to establish whether this difference was statistically significant as shown on Table 11: 


\begin{tabular}{|c|c|c|c|c|c|c|}
\hline & & d & df & $\begin{array}{c}\text { Sig. (2- } \\
\text { tailed) }\end{array}$ & $\begin{array}{c}\text { Mean } \\
\text { Difference }\end{array}$ & $\begin{array}{c}\text { Std. Error } \\
\text { Difference }\end{array}$ \\
\hline \multirow{2}{*}{$\begin{array}{c}\text { mean } \\
\text { academic use }\end{array}$} & Equal variances assumed & -1.659 & 221 & .098 & -.22527 & .13575 \\
\cline { 2 - 7 } & $\begin{array}{c}\text { Equal variances not } \\
\text { assumed }\end{array}$ & -1.646 & 206.810 & .101 & -.22527 & .13686 \\
\hline
\end{tabular}

Table 12: T-Test of Private and Public University Students on ICT Use

The results in Table 12 show that there were no statistically significant differences among teacher education students in private and public universities in utilisation of ICTs. This is because the computed t-value obtained from the results was 0.098 at a significance level of 0.05 .

\section{Findings}

- A significant number of students owned and used the mobile telephone off campus not only for communication but also for internet access, taking photographs, listening to radio FM radio stations, among other uses;

- Students had relevant skills to effectively use some ICTs in their studies such as use of e-mail and word processing. However, the use of search engines (software systems designed for obtaining information on the World Wide Web) was poor perhaps because it required a higher level of technical skills and knowledge, which students appeared not to posses. Other ICT applications (such as video and audio files, discussion forums and digital libraries) tended to be advanced for those without specific know-how on their use and therefore were lowly used

- Students depended more on institutional facilities although they were able to access a variety of ICT services (such as computer and internet use, radio and television) off campus in cyber cafés;

- Students in both public and private universities used ICTs frequently for study related activities such as sending email to lecturers on course issues, doing assignments and other study-related tasks, and for general reference to supplement lecture notes;

- $\quad$ Students indicated that ICT provided them with better learning opportunities and that their use saved study time. These advantages would imply that ICTs had numerous attributes which made them popular with students;

3.1. Influence of User Characteristics on Utilization of ICTs Among Teacher Education Students and Lecturers in Universities in Kenya findings:

With regard to the influence of user characteristics on utilization of ICTs, the study came up with the following

- Both male and female students had good access to various ICT facilities on campus and they used them frequently. However, fewer students of either gender used laptops probably because of the high cost of obtaining them;

- Female students had a marginally higher usage of the internet; however, male students had higher use of all other ICT types;

- More male than female students reported possession of a higher level of competence in the use of e-mail and search engines. However, more females than males reported higher competencies on applications such as Word Processing; PowerPoint presentations and Instant Messenger;

- Most Universities lacked an e-learning policy. This implies lack of clear guidelines that supported provision, use and maintenance of ICT facilities. At the same time, absence of clear e-learning policies and guidelines may be reflected into low quality ICT services;

\section{Conclusion}

The following conclusions were arrived at on the basis of these findings:-

- Substantial investments had been made to procure various ICTs and internet provision in private and public universities and students were using them frequently for educational purposes;

- Students needed additional training and encouragement on utilizing some ICT applications such as PowerPoint presentations, video and audio files, discussion forums and digital libraries which may result in invaluable educational benefit to students in ICT use;

- Students needed appropriate technical support to utilize various ICTs for learning and teaching. Therefore, additional technical support staff may contribute to improved utilization of ICTs in universities;

- Unreliable electricity/ power supply contributed negatively to effective utilization of various ICTs for educational purposes among students in universities in Kenya. Notably, some universities had invested in back-up power generators;

- Universities had no ICT-use policies to guide teacher education students. Such e-learning policies and guidelines are essential in supporting the provision, use and maintenance of ICT facilities and infrastructure. 


\section{Recommendations}

Based on the conclusions above, the study made the following recommendations:

- The universities should design and conduct ICT-use courses among teacher education students in universities in Kenya;

- The university management should strengthen the technical support available for use among teacher education students and lecturers in universities in Kenya;

- The university management and government should invest in alternative power sources so as to limit the interruptions due to unreliable mains electricity;

- The universities should design and implement ICT-use policies that can be integrated into teacher education programmes. Such policies can improve the lecturers' attitude towards using ICTs for teaching, presentation or reference in class. Consequently, students' who look up to them as role models may be positively impacted as well;

- The government should initiate sustainable financial mechanisms through relevant departments to provide laptops and computers to students in universities in order to reduce the dependence on institutional ICTs. As a starting point, other phases of the wezesha laptop initiative can be implemented.

\section{References}

i. $\quad$ Cohen, L. and Manion, L. (1997). Research Methods in Education. London: Routledge

ii. Eynon, R (2005). The Use of the Internet in Higher Education: Academics' Experiences of Using ICTs for Teaching and Learning. Aslib Proceedings: New Information Perspectives. 57(2),168-180.

iii. GoK (2008) .The National Strategy for University Education, 2007-2015 (A report prepared by the Taskforce for the Development of the National Strategy for University Education)

iv. GoK (2007). Kenya Vision 2030: A Globally Competitive and Prosperous Kenya (Accessed from: www. egovernement.go.ke on 4th Febraury 2009)

v. GoK (2006). The National Information and Communications Technology (ICT) Policy.

vi. $\quad$ Online: www. e-governement.go.ke (downloaded 4 th February 2009)

vii. $\quad$ GoK (2005) Sesional Paper No.1 2005 on A Policy Framework for Education, Training and Research.

viii. Kirkwood, A (2007). Getting it from the Web: Why and How Online Resources are Used by Independent Undergraduate Learners. Journal of Computer Assisted Learning 24, (372-382).

ix. Mahmood, K (2009). Gender, Subject and Degree Differences in University Students' Access, Use and Attributes Toward Information and Communication Technology (ICT). International Journal of Education and Development using Information and Communication Technology (IJEDICT), 5(3), 206-216.

x. Moser, C.A and Kalton, G. (1971). Survey Methods in Social Investigation. London: Heinemann Educational Books.

xi. Mugenda, O.M and Mugenda, A.B (1999). Research Methods: Quantitative and Qualitative Approaches. Nairobi: Acts Press

xii. Nasah, A et al (2010).The Digital Literacy Debate: An Investigation of Digital Propensity and Information and Communication Technology. Education Tech Research Dev 58, 531-555.

xiii. Oyelaran-Oyeyinka, B and Adeya, C.N (2004). Dynamics of Adoption and Usage of ICTs in AfricanUniversities: A Study of Kenya and Nigeria. Technovation. 24(2004), 841-851.

xiv. Pittman, J(2007). Converging Instructional and Critical Intercultural Pedagogy in Teacher Education. Multicultural Education \& Technology Journal. 1(4), 200-221

xv. Potashnik, Mand Adkins, D (1996). Cost Analysis of Information Technology Projects in Developing Countries. Education and Technology. series 1(3). Washington D.C: The World Bank.

xvi. Sanchez, J and Salinas, A (2008). ICTS and Learning in Chilean Schools: Lessons Learnt.Computers \& Education.51(2008), 1621-1633.

xvii. Shi, L. (2003). Tensions in Learning Content and Technology: The experience of education Students in a Web-based research Project. Journal of Information Technology, Pedagogy and Education. 12 (1), 2003, 5-17. Simsek, C.S.S (2008). Students Attitudes Towards Integration of ICTs in a Reading Course: A case in Turkey. Computers \& Education. 51(2008), 200-211.

xviii. $\quad$ UN (2004) UN Millennium Development Goals. Available online at: www.un.org/ millenniumgoals/ .(Accessed 20th Feb 2009).

xix. UNDP. (2003). Human Development Report 2003 - Millennium Development Goals: A compact among nations to end human poverty. New York: Oxford University Press.

xx. UNESCO (2002a). Information and Communication Technologies in Teacher Education: A Planning Guide. Paris: Division of Higher Education.

xxi. UNESCO (2002b). Teacher education Guidelines: Using Open and Distance Learning.Paris: Teacher Education Section xxii. UNU (2008). 'Innovative Capacity Development Through e-Learning with a Special Focus on Africa'. UN Campus, Bonn, Germany.

xxiii. Unwin, T (2008). Survey of e-Learning in Africa.UNITWIN/ UNESCO: Royal Holloway, University of London, UK. 
xxiv. Unwin, T (2005). Towards a Framework for the Use of ICT in Teacher Training in Africa. Open Learning. 20(2), $113-129$.

xxv. Valasidou, A and Bousiou-Makridou, D (2008). The Impact of ICTs in Education:The Case of University of Macedonia Students. Journal of Business Case Studies. 4(3), 29-34.

xxvi. Valasidou, A, Sinopoulos, D, Hatzis, T and Bousiou-Makridou, D (2005). 'Guidelines for the Design and Implementation of E-Learning programmes'. Proceedings of the IADIS International Conference, IADIS E-Society 2005, 27-30 June, Qawra, Malta and Communication Technology. (IJEDICT),3(1),5-22.

xxvii. Wezesha (2011). Subsidized Laptops for Kenyan University Students- Real ICT4 Edu Investment. Accessed online on 7/9/11 from: www.ictworks.org. 